\title{
MOBILIDADE HUMANA E A DIVERSIDADE SÓCIO-CULTURAL*
}

\author{
SZILVIA SIMAI ${ }^{* *}$ \\ ROSANA BAENINGER ${ }^{* * *}$
}

A

ideia principal do livro está assentada na importância das migrações, tanto em nível local quanto em nível global, para a (trans)formação de culturas. O livro deixa claro que a própria cultura, por sua vez, está "migrante". Avança ainda no estudo da multiplicidade de contextos culturais sobre a migração. Foi produzido por vários estudiosos que abordam questões relativas à cultura e suas interrelações com a mobilidade humana. Para tanto, utilizam uma variedade de situações, disciplinas e metodologias, contemplando aspectos relevantes da presente conjuntura da migração e cultura: questões da trajetória do deslocamento; fronteiras; identidades; contatos transnacionais; memória cultural; transmissão da identidade através das gerações; as questões de diferença cultural e hibridismo; histórias orais da migração; o papel das novas tecnologias de ligação entre culturas e a promoção cultural da polinização cruzada.

A coletânea tem duas partes principais. A primeira parte mostra muito bem como o estudo da migração envolve inúmeras possíbilidades de rotas disciplinares e de metodologias de pesquisa. A forma mais comum de encontrar estudos migratórios é no âmbito das ciências sociais. Na verdade, no Brasil, a Associação Nacional de Pós-Graduação e Pesquisa em Ciências Sociais (Anpocs) e a Associação Brasileira de Estudos Populacionais (Abep) têm grupos de trabalho que tratam da migração internacional; outras áreas humanísticas e das artes, contudo, não parecem reconhecer o seu interesse distinto no campo. Essa fronteira é destruída no livro por estudiosos, unificando as ciências sociais e as artes. E assim, nessa perspectiva, na primeira parte do livro, os autores apresentam uma rica coleção interdisciplinar sobre a mobilidade humana. Alguns artigos do livro usam uma abordagem mais moderna das ciências

\footnotetext{
* Resenha do livro organizado por Débora Mazza e Olga von Simson (Jundiaí: Paco Editorial, 2011).

* Doutora em Psicologia Social e pesquisadora do Núcleo de Estudos de População da Universidade Estadual de Campinas (Unicamp).E-mail: szilvia.simai@gmail.com

*** Doutora em Ciências Sociais e professora do Departamento de Demografia e Núcleo de Estudos de População da Universidade Estadual de Campinas (Unicamp). E-mail: baeninge@nepo.unicamp.br
} 
sociais para trazer elementos de estudos de mídia, de sociologia e de psicologia social. O lado mais forte da obra é a inclusão de campos muito pouco discutidos, como a análise literária de Albert Camus em uma conceituação filosófica da estranheza e alteridade através de análise semiótica e pós-colonial. Destaque-se também a voz que é dada às crianças como protagonistas de suas vidas, isso mostra a capacidade do livro em trazer elementos inovadores e sofisticados para análise de estudos migratórios. A obra traz ainda o uso do cinema como uma forma de retratar experiências migratórias, bem como as novas formas de internacionalizações e suas migrações, envolvendo trajetórias migratórias acadêmicas, o que enriquece nossa compreensão acerca das mobilidades humanas contemporâneas como experiências vividas.

A segunda parte do livro focaliza e reconstrói movimentos migratórios internacionais para o Brasil, destacando a importância da mulher nesses contextos migratórios. Italianas, portuguesas, alemãs, japonesas e latino-americanas compõem o universo social das migrações no Brasil. Nesse aspecto, o livro é oportuno e inovador, ao dar visibilidade às mulheres imigrantes e sua importância nas constituições dos fenômenos migratórios históricos e contemporâneas.

A presença da mulher imigrante é retratada de maneira exemplar no livro, desde as vivências familiares nas ex-colonias portuguesas até as mulheres latinas hoje na cidade de São Paulo. A leitura da coletânea permite um percurso pela presença da mulher imigrante a partir de diferentes olhares: na música, na família imigrante, nas gerações de imigrantes, nas relações de gênero, na educação, na formação de identidades das mulheres imigrantes; aspectos que refletem e dinamização do processo cultural.

O livro faz-nos compreender que a mobilidade humana traz desafios intermináveis e dificuldades vividas por todos os migrantes e, de uma forma ou de outra, características comumente compartilhadas. Contudo, no fim, estes desafios se tornam parte de processos identitários e da construção social das migrações e dos indivíduos neles envolvidos. Como Hemingway afirma: “O mundo quebra todo mundo e, posteriormente, alguns ficam mais fortes nos locais quebrados". 